\title{
An Examination of the U.S. Collegiate Aviation Workforce in Preparing the Next Generation of Aviation Faculty Members Beyond 2000
}

\author{
Jeffrey A. Johnson \\ Aviation Institute \\ University of Nebraska at Omaha
}

\begin{abstract}
Aviation as an academic field of study has evolved in the span of a century. As the new millennium approaches, collegiate aviation will be called upon to prepare a new generation of highly skilled workers. These workers need to be educated by current and future generations of aviation faculty members. The purpose of this study was to examine the US collegiate aviation workforce to determine if the next generation of faculty members are being adequately prepared. A descriptive study survey questionnaire was used to collect data for this study which was sent to US University Aviation Association (UAA) institutional members in order to ascertain their workforce needs. The study found that a significant amount of hiring for qualified aviation faculty members is already occurring. The survey results also indicated a substantial number of retirements is either taking place or is anticipated to take place by the year 2000. A very significant finding was that almost all of the respondents believe the public at large does not have an adequate understanding of collegiate aviation.
\end{abstract}

\section{INTRODUCTION AND BACKGROUND}

During the twentieth century, the entire field of aviation has advanced tremendously. From the historic flight at Kitty Hawk to routine daily transoceanic flights carrying a seemingly countless number of passengers from all walks of life, aviation still seems to be evolving at phenomenal rates. In the US alone, there are over 500 colleges and universities that offer some type of aviation related program (Collegiate Aviation Guide, 1994). According to Fuller and Truitt (1997), the academic field of aviation has matured from a more historic technical/vocational orientation to a present day contemporary study involving science, business and public administration, technology, and the social sciences found in modern day colleges and universities. These changes in the academic field of aviation have necessitated changes in the aviation educator's role as well. As the aviation academic field continues to evolve, a new generation of aviation faculty members must be prepared to fulfill the personnel needs of the industrial, governmental, and academic sectors of aviation beyond the year 2000 .

Educators have several formidable challenges in preparing a new generation of aviation faculty members. The first challenge lies in the area of minimum requirements for employment. Unlike many traditional academic fields of study in higher education (e.g., history and philosophy) where the minimum benchmark for prospective faculty members is an earned doctoral degree, the 
benchmark for the prospective aviation faculty member is often more demanding. Unlike history and philosophy, aviation's technical/ vocational orientation started at the airfield and has evolved into a complex multi disciplinary academic field of study found in many colleges and universities (Fuller \& Truitt, 1977). This evolution has precipitated a need for aviation faculty members to possess not only a graduate degree (with greater emphasis on the doctorate) and preferential teaching experience, but actual aviation practitioner oriented field experience combined with professional certification credentials.

Another challenge that seems to plague collegiate aviation is residual negative public perception. This adverse perception of aviation as a legitimate field of academic study still creates hurdles for current aviation faculty members to overcome and may hinder new faculty member entrants. Fortunately, there is evidence that improvement in public perception is gaining momentum. During the 1970s, the Dean of University of North Dakota (UND) School of Aerospace Sciences, John Odegard, stated, "The acceptability of aviation in the academic community has been painfully slow, but improvement appears to be rapidly on the upswing" (Matson, 1977, p. 178). By 1997, former president of Embry-Riddle Aeronautical University, Steven Sliwa, argued that aviation had still not reached general acceptance in higher education (University Aviation Association Newsletter, 1997). Specific areas of negative public perception may possibly include aviation's recent entrance to higher education in comparison to traditional fields of study, an absence of a longstanding record in research (Truitt \& Kaps, 1995), and beliefs held by some traditional academicians that aviation belongs in technical schools and not colleges and universities.

Another area that has continually plagued aviation educators is a failure to reach a consensus on how educators collectively identify academic programs in the field. In a study conducted by Johnson (1997), 14 different terms or phrases were used by aviation educators to identify collegiate aviation.

\section{METHODOLOGY}

\section{Subjects}

The population for this study included all US UAA institutional members. The November 1997 UAA membership list indicated there were 100 US institutional members. Key assumptions made about the subjects during the study included: (a) University Aviation Association institutional members as representative experts in their field; (b) the data generated from the institutional members can be used to accurately assess how well aviation educators are doing in preparing a future generation of aviation faculty members; (c) the institutional members were current in academic matters concerning their hiring needs and could make reasonable assumptions about future hiring needs; and (d) the members responded to the questionnaire in a sincere manner using their professional, educational, and experiential expertise.

\section{Research Instrument}

The instrument used to collect the data was a survey questionnaire developed specifically for the study. The survey was distributed to all 100 US member institutions via US mail. A usable return rate of 56 surveys $(56.0 \%)$ was received for the study. The survey was comprised of two sections. The first section incorporated a series of 
questions posed to the institutional members concerning their aviation faculty recruitment needs, hiring requirements, salary structures, experiential knowledge of their new hires, etc. In response to the survey questions, respondents were directed to choose from a series of short statements ranging from yes/no responses to minimum educational requirements. The second section of the survey instrument incorporated a demographic section. Responses left blank by institutional members were indicated by N/R (Not Reported). In evaluating the data presented in the following tables, rounding errors should be taken into consideration.

\section{DATA ANALYSIS}

\section{Demographics}

Data from the survey questionnaires were compiled from the software program, Minitab (1998). Demographic characteristics included gender, highest degree held, position, institutional affiliation, employment status, and institutional longevity. Of the 56 respondents, 55 $(98.2 \%)$ are male, $46(82.1 \%)$ are employed at a public institution, $26(46.4 \%)$ are tenured, and $15(26.8 \%)$ have at least 16 years of employment experience at their present institution. Thirty UAA institutional members $(53.4 \%)$ are 51 years of age or older, $35(62.5 \%)$ have 10,000 students or less at their institutions, $26(46.5 \%)$ are at the associate professor level or higher, and $22(39.3 \%)$ are employed at doctoral granting institutions of higher education. The percentage of female UAA institutional representatives in collegiate aviation has remained relatively unchanged from 1993 to 1998 (see Table 1). The percentages of female aviation faculty members depicted in Table 1 still remain far below the national average of 32.5 percent as indicated by the 1992 data from the US Department of
Education (cited in The Chronicle of Higher Education: Almanac Issue, 1997).

Table 1

Gender by Year

\begin{tabular}{|l|l|l|l|l|}
\hline & $\begin{array}{l}\text { Female } \\
\mathrm{N} \%\end{array}$ & $\begin{array}{l}\text { Male } \\
\mathrm{N} \%\end{array}$ & $\begin{array}{l}\mathrm{N} / \mathrm{R} \\
\mathrm{N} \%\end{array}$ & $\begin{array}{l}\text { Total } \\
\mathrm{N} \%\end{array}$ \\
\hline $1993^{*}$ & 5 & 74 & 0 & 79 \\
& $(6.4)$ & $(93.8)$ & $(0.0)$ & $(100.0)$ \\
\hline $1996 * *$ & 1 & 74 & 0 & 75 \\
& $(1.3)$ & $(98.7)$ & $(0.0)$ & $(100.0)$ \\
\hline 1998 & 4 & 51 & 1 & 56 \\
& $(7.1)$ & $(91.1)$ & $(1.8)$ & $(100.0)$ \\
\hline
\end{tabular}

Note. The data in row $1 *$ are from The Feasibility of Developing a Profession-ally Accredited Non-Engineering Aeronautical/Aerospace Science Doctoral Degree Program in US Universities (p. 38) by J. A. Johnson, 1993, Ann Arbor, MI: Master's Abstracts International. The data from row $2 * *$ are from An Analysis of Curriculum Design in Developing a Doctor of Philosophy Program in Aeronology (p. 59) by J. A.

Johnson, 1997, Ann Arbor, MI: Dissertation Abstracts International.

Percentage wise, Table 2 illustrates a relatively stable trend in the highest degree held by UAA institutional member respondents in collegiate aviation during a recent five year period. Note that approximately one-half of the respondents have a master's degree as the highest degree held while only one-third of the respondents have a doctoral degree. Likewise, respondents in possession of an associate's degree as the highest degree held represent a very small percentage of all the respondents during the same time frame. 
Table 2

Respondents' Highest Degree Held vs. Year

\begin{tabular}{|l|l|l|l|l|l|}
\hline & $\begin{array}{l}\text { Asso- } \\
\text { ciate } \\
\text { N \% }\end{array}$ & $\begin{array}{l}\text { Bache- } \\
\text { lor's } \\
\text { N \% }\end{array}$ & $\begin{array}{l}\text { Master's } \\
\text { N \% }\end{array}$ & $\begin{array}{l}\text { Doc- } \\
\text { torate } \\
\text { N \% }\end{array}$ & $\begin{array}{l}\text { Total } \\
\text { N \% }\end{array}$ \\
\hline $1993^{*}$ & $\begin{array}{l}3 \\
(3.8)\end{array}$ & $\begin{array}{l}11 \\
(13.9)\end{array}$ & $\begin{array}{l}42 \\
(53.2)\end{array}$ & $\begin{array}{l}23 \\
(29.1)\end{array}$ & $\begin{array}{l}79 \\
(100.0)\end{array}$ \\
\hline $\begin{array}{l}1996^{*} \\
*\end{array}$ & 1 & 13 & 32 & 28 & 74 \\
$(1.3)$ & $(17.3)$ & $(42.7)$ & $(37.3)$ & $(100.0)$ \\
\hline 1998 & 1 & 6 & 29 & 18 & 54 \\
& $(1.9)$ & $(11.1)$ & $(53.7)$ & $(33.3)$ & $(100.0)$ \\
\hline
\end{tabular}

Note. The data in row $1^{*}$ are from The Feasibility of Developing a Professionally Accredited

Non-Engineering Aeronautical/Aerospace Science Doctoral Degree Program in US Universities (p. 39) by J. A. Johnson, 1993, Ann Arbor, MI: Master's Abstracts International. The data from row $2 * *$ are from An Analysis of Curriculum Design in Developing a Doctor of Philosophy Program in Aeronology ( $p$. 59) by J. A. Johnson, 1997, Ann Arbor, MI: Dissertation Abstracts International.

\section{Data Tabulations}

The data from the study were incorporated into a series of tables. Some of the data illustrated in this section have been cross tabulated using demographic information to illustrate comparisons. In Table 3, almost one-half ( $\underline{N}=24,42.8 \%)$ of the respondents are recruiting faculty members predominantly at public institutions $\quad(\underline{N}=20, \quad 35.7 \%)$. Four respondents $(7.1 \%)$ at private institutions are reportedly hiring faculty members. The hiring activity is indicative of the importance for all of collegiate aviation to actively encourage careers in the field.
Table 3

Respondents' Institutional Affiliation and Recruitment Status for Hiring Aviation Faculty Members at the Instructor, Assistant Professor, Associate Professor, or Professor Ranks

\begin{tabular}{|l|l|l|l|l|}
\hline & $\begin{array}{l}\text { Public } \\
\mathrm{N} \%\end{array}$ & $\begin{array}{l}\text { Private } \\
\mathrm{N} \%\end{array}$ & $\begin{array}{l}\mathrm{N} / \mathrm{R} \\
\mathrm{N} \%\end{array}$ & $\begin{array}{l}\text { Total } \\
\underline{\mathrm{N}} \%\end{array}$ \\
\hline Hiring & 20 & 4 & 0 & 24 \\
& $(35.7)$ & $(7.1)$ & $(0.0)$ & $(42.8)$ \\
\hline Not & 25 & 5 & 1 & 31 \\
Hiring & $(44.6)$ & $(8.9)$ & $(1.8)$ & $(55.4)$ \\
\hline N/R & 1 & 0 & 0 & 1 \\
& $(1.8)$ & $(0.0)$ & $(0.0)$ & $(1.8)$ \\
\hline Total & 46 & 9 & 1 & 56 \\
& $(82.1)$ & $(16.0)$ & $(1.8)$ & $(100.0)$ \\
\hline
\end{tabular}

Out of the 24 respondents $(42.8 \%)$ hiring faculty members depicted in Table 4 , most of the hiring taking place is at doctoral granting institutions of higher education $(\underline{N}=11$, $19.6 \%$ ) followed by community colleges $(\underline{N}=7,12.5 \%)$. The least amount of hiring taking place is at bachelor degree granting institutions $(\underline{N}=1,1.8 \%)$. Some hiring activity at master's degree granting institutions is also occurring ( $\underline{\mathrm{N}}=5,8.9 \%$ ). With respect to hiring inactivity, doctoral and associate degree granting institutions are evenly split at 11 members apiece $(19.6 \%)$. 
Table 4

Highest Degree Offered by Respondents' Institutions and Recruitment Status for Hiring Aviation Faculty Members at the Instructor, Assistant Professor, Associate Professor, or Professor Ranks

\begin{tabular}{|l|l|l|l|l|l|}
\hline & $\begin{array}{l}\text { Asso- } \\
\text { ciate } \\
\mathrm{N} \%\end{array}$ & $\begin{array}{l}\text { Bache- } \\
\text { lor's } \\
\mathrm{N} \%\end{array}$ & $\begin{array}{l}\text { Master's } \\
\mathrm{N} \%\end{array}$ & $\begin{array}{l}\text { Doc- } \\
\text { torate } \\
\mathrm{N} \%\end{array}$ & $\begin{array}{l}\text { Total } \\
\mathrm{N} \%\end{array}$ \\
\hline Hiring & $\begin{array}{l}1 \\
(12.5)\end{array}$ & $\begin{array}{l}1 \\
(1.8)\end{array}$ & $\begin{array}{l}5 \\
(8.9)\end{array}$ & $\begin{array}{l}11 \\
(19.6)\end{array}$ & $\begin{array}{l}24 \\
(42.8)\end{array}$ \\
\hline Not & 11 & 4 & 5 & 11 & 31 \\
Hiring & $(19.6)$ & $(7.1)$ & $(8.9)$ & $(19.6)$ & $(55.4)$ \\
\hline N/R & 0 & 1 & 0 & 0 & 1 \\
& $(0.0)$ & $(1.8)$ & $(0.0)$ & $(0.0)$ & $(1.8)$ \\
\hline Total & $\begin{array}{l}18 \\
(32.1)\end{array}$ & $\begin{array}{l}6 \\
(10.7)\end{array}$ & $\begin{array}{l}10 \\
(17.9)\end{array}$ & $\begin{array}{l}22 \\
(39.2)\end{array}$ & $\begin{array}{l}56 \\
(100.0)\end{array}$ \\
\hline
\end{tabular}

The data illustrated in Table 5 illustrate parallel trends to the data previously illustrated in Table 4. Note that in Table 4, 11 UAA institutional members $(19.6 \%)$ at doctoral granting institutions are currently hiring compared to the same number of respondents who reported retirements or anticipated retirements in Table 5. The number of respondents reporting retirements substantially drops to four $(7.1 \%)$ at master's degree granting institutions, two $(3.6 \%)$ at four-year degree institutions, and three $(5.4 \%)$ at community colleges. Slightly over one-quarter of all non-retirements are concentrated at the community colleges ( $\underline{N}=15,26.8 \%)$.
Table 5

Highest Degree Offered by Respondents' Institutions Versus Reported or Anticipated Retirements by the Year 2000

\begin{tabular}{|l|l|l|l|l|l|}
\hline & $\begin{array}{l}\text { Asso- } \\
\text { ciate } \\
\mathrm{N} \%\end{array}$ & $\begin{array}{l}\text { Bache- } \\
\text { lor's } \\
\mathrm{N} \%\end{array}$ & $\begin{array}{l}\text { Master's } \\
\mathrm{N} \%\end{array}$ & $\begin{array}{l}\text { Doc- } \\
\text { torate } \\
\underline{\mathrm{N}} \%\end{array}$ & $\begin{array}{l}\text { Total } \\
\underline{\mathrm{N}} \%\end{array}$ \\
\hline Retire & 3 & 2 & 4 & 11 & 20 \\
& $(5.4)$ & $(3.6)$ & $(7.1)$ & $(19.6)$ & $(35.7)$ \\
\hline None & 15 & 4 & 5 & 11 & 35 \\
& $(26.8)$ & $(7.1)$ & $(8.9)$ & $(19.6)$ & $(62.5)$ \\
\hline $\mathrm{N} / \mathrm{R}$ & 0 & 0 & 1 & 0 & 1 \\
& $(0.0)$ & $(0.0)$ & $(1.8)$ & $(0.0)$ & $(1.8)$ \\
\hline Total & $\begin{array}{l}6 \\
(32.2)\end{array}$ & $\begin{array}{l}6 \\
(10.7)\end{array}$ & $\begin{array}{l}10 \\
(17.9)\end{array}$ & $\begin{array}{l}22 \\
(39.2)\end{array}$ & $\begin{array}{l}56 \\
(100.0)\end{array}$ \\
\hline
\end{tabular}

Table 6 indicates that a significant majority of the UAA respondents $(\underline{N}=35$, $62.5 \%$ ) require the master's degree as a minimum educational requirement for faculty new hires. Nine respondents (16.1\%) report the bachelor's degree as a minimum prerequisite followed by seven (12.5\%) who require the doctorate. Four respondents $(7.1 \%)$ in the Other category have indicated specialized expertise in the form of a license or professional certification as a minimum educational requirement. Only one UAA institutional member (1.8\%) did not respond.

\section{Table 6}

Minimum Educational Requirements for Aviation Faculty New Hires

\begin{tabular}{|l|l|l|l|l|l|}
\hline $\begin{array}{l}\text { Bachelor's } \\
\mathrm{N} \%\end{array}$ & $\begin{array}{l}\text { Master's } \\
\mathrm{N} \%\end{array}$ & $\begin{array}{l}\text { Doctorate } \\
\mathrm{N} \%\end{array}$ & Other & $\mathrm{N} / \mathrm{R}$ & Total \\
\hline 9 & 35 & 7 & 4 & 1 & 56 \\
$(16.1)$ & $(62.5)$ & $(12.5)$ & $(7.1)$ & $(1.8)$ & $(100.0)$ \\
\hline
\end{tabular}

As shown in Table 7, slightly less than one-quarter of all the UAA respondents $(\underline{\mathrm{N}}=22,39.3 \%)$ believe that collegiate aviation is average in its effectiveness to promote and prepare a future generation of faculty members. Moreover, collegiate aviation's overall effectiveness does not seem to "make the grade" when combining Below Average

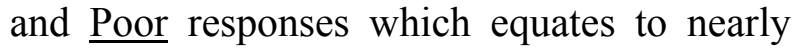


one-half $(\underline{\mathrm{N}}=25,44.6 \%)$ of the institutional membership who responded to the survey questionnaire. No one indicated that collegiate aviation's effectiveness was in the Excellent category while slightly less than one-fifth $(\underline{N}=9,16.1 \%)$ of the reported membership was in the Good category.

\section{Table 7}

Collegiate Aviation's Effectiveness in Promoting and Preparing a Future Generation of Faculty Members

\begin{tabular}{|l|l|l|l|l|l|}
\hline $\begin{array}{l}\text { Excel- } \\
\text { lent } \\
\underline{\mathrm{N}} \%\end{array}$ & $\begin{array}{l}\text { Good } \\
\underline{\mathrm{N}} \%\end{array}$ & $\begin{array}{l}\text { Average } \\
\underline{\mathrm{N}} \%\end{array}$ & $\begin{array}{l}\text { Below } \\
\text { Average } \\
\mathrm{N} \%\end{array}$ & $\begin{array}{l}\text { Poor } \\
\underline{\mathrm{N}} \%\end{array}$ & $\begin{array}{l}\text { Total } \\
\underline{\mathrm{N}} \%\end{array}$ \\
\hline 0 & 9 & 22 & 16 & 9 & 56 \\
$(0.0)$ & $(16.1)$ & $(39.3)$ & $(28.5)$ & $(16.1)$ & $(100.0)$ \\
\hline
\end{tabular}

Table 8 illustrates the UAA respondents' perceptions of their own salary structure in comparison to other aviation programs. Nearly one-half of the respondents $(\underline{N}=26$, $46.4 \%$ ) believe their salary structures are average in comparison to other programs. Only 3 respondents (5.4\%) reported their salary structure as Poor. When combining Excellent and Good responses, slightly over one-quarter $(\underline{N}=15,26.8 \%)$ of the members consider their salary structure better than average in comparison to other programs. Note the number of respondents in the Excellent/Good category equals the number of respondents in the Below Average/Poor category $(\underline{N}=15,26.8 \%)$. In essence, a normal distribution exists around the concentration of Average responses.

\section{Table 8}

Respondents' Reported Salary Structure in Comparison to Other Aviation Programs

\begin{tabular}{|l|l|l|l|l|l|}
\hline $\begin{array}{l}\text { Excel- } \\
\text { lent } \\
\mathrm{N} \%\end{array}$ & $\begin{array}{l}\text { Good } \\
\mathrm{N} \%\end{array}$ & $\begin{array}{l}\text { Average } \\
\underline{\mathrm{N}} \%\end{array}$ & $\begin{array}{l}\text { Below } \\
\text { Average } \\
\underline{\mathrm{N}} \%\end{array}$ & $\begin{array}{l}\text { Poor } \\
\underline{\mathrm{N}} \%\end{array}$ & $\begin{array}{l}\text { Total } \\
\underline{\mathrm{N}} \%\end{array}$ \\
\hline 7 & 8 & 26 & 12 & 3 & 56 \\
$(12.5)$ & $(14.3)$ & $(46.4)$ & $(21.4)$ & $(5.4)$ & $(100.0)$ \\
\hline
\end{tabular}

The distribution of responses in Table 8 has a strong resemblance to the distribution of responses in Table 9. Again, nearly one-half of the respondents $(\underline{N}=26,46.4 \%)$ believe their salary with respect to cost of living is average. Only one individual reported an earned salary vs. cost of living as Excellent. Collectively though, exactly one-quarter of the respondents $(\underline{\mathrm{N}}=14,25.0 \%)$ report their salaries as Excellent/Good. Thirteen (23.3\%) of the reported UAA institutional membership report their salary as Below Average and only three members $(5.4 \%)$ report a response of Poor.

\section{Table 9}

Respondents' Reported Salaries With Respect to Cost of Living

\begin{tabular}{|l|l|l|l|l|l|}
\hline $\begin{array}{l}\text { Excel } \\
\text {-lent } \\
\mathrm{N} \%\end{array}$ & $\begin{array}{l}\text { Good } \\
\mathrm{N}\end{array}$ & $\begin{array}{l}\text { Average } \\
\mathrm{N} \%\end{array}$ & $\begin{array}{l}\text { Below } \\
\text { Average } \\
\mathrm{N} \%\end{array}$ & $\begin{array}{l}\text { Poor } \\
\mathrm{N} \%\end{array}$ & $\begin{array}{l}\text { Total } \\
\underline{\mathrm{N}} \%\end{array}$ \\
\hline 1 & 13 & 26 & 13 & 3 & 56 \\
$(1.8)$ & $(23.2)$ & $(46.4)$ & $(23.2)$ & $(5.4)$ & $(100.0)$ \\
\hline
\end{tabular}

Table 10 provides an illustration of the UAA institutional members' aviation program salary ranges. Reported salaries are clustered in the $\$ 20,000-\$ 59,000$ range. The most prolific response was the $\$ 40,000$ - $\$ 59,000$ salary range reported by 36 respondents $(64.3 \%)$. According to US Department of Education (as cited in The Chronicle of Higher Education: Almanac Issue, 1997), the average salary for all institutions of higher education adjusted for a nine month academic year (except those without academic ranks) are as follows: Professor, \$67,415; Associate Professor, \$49,695; Assistant Professor, $\$ 41,041 ; \quad$ Instructor, $\$ 31,756$; Lecturer, $\$ 34,755$; and No Rank, $\$ 36,502$. The overall average salary was $\$ 52,556$. Table 10 also depicts a very small percentage of salaries in the Less than $\$ 20,000$ and the $\$ 100,000$ or more category ranges at one response $(1.8 \%)$ per category. Respondents reporting in the $\$ 80,000$ - $\$ 99,000$ category also comprise a very small percentage $(\underline{\mathrm{N}}=2,3.6 \%)$. 
Table 10

Reported Salary Ranges

by UAA Institutional Members

\begin{tabular}{|l|l|l|}
\hline Less than & $\$ 20,000-$ & $\$ 40.000-$ \\
$\$ 20,000$ & $\$ 39,000$ & $\$ 59,000$ \\
$\underline{\mathrm{N}} \%$ & $\underline{\mathrm{N} \%}$ & $\underline{\mathrm{N}} \%$ \\
\hline 1 & 32 & 36 \\
$(1.8)$ & $(57.1)$ & $(64.3)$ \\
\hline$\$ 60,000-$ & $\$ 80,000-$ & $\$ 100,000$ \\
$\$ 79,000$ & $\$ 99,000$ & or more \\
$\underline{\mathrm{N}} \%$ & $\underline{\mathrm{N}} \%$ & $\underline{\mathrm{N}} \%$ \\
\hline 10 & 2 & 1 \\
$(17.9)$ & $(3.6)$ & $(1.8)$ \\
\hline
\end{tabular}

Note. Respondents were able to list more than one salary range.

In Table 11, 55 out of the 56 responding members indicated that public perception of collegiate aviation is inadequate. None of the members indicated adequate public perception. Only one respondent $(1.8 \%)$ did not respond.

Table 11

Does the Public At Large Have an Adequate Understanding of Collegiate Aviation?

\begin{tabular}{|l|l|l|l|}
\hline Yes & No & $\mathrm{N} / \mathrm{R}$ & Total \\
$\mathrm{N} \%$ & $\underline{\mathrm{N}} \%$ & $\underline{\mathrm{N}} \%$ & $\underline{\mathrm{N}} \%$ \\
\hline 0 & 55 & 1 & 56 \\
$(0.0)$ & $(98.2)$ & $(1.8)$ & $(100.0)$ \\
\hline
\end{tabular}

\section{CONCLUSIONS AND RECOMMENDATIONS}

\section{Conclusions}

Overall, 24 UAA respondents $(42.8 \%)$ indicated they were actively hiring new aviation faculty members for their programs. Most of the hiring taking place is at doctoral granting institutions of higher education $(\underline{\mathrm{N}}=11,19.6 \%$ ) followed by community colleges $(\underline{\mathrm{N}}=7,12.5 \%)$. Data results also indicate that 11 doctoral institutions (19.6\%) are either losing faculty members to retirements or will be losing faculty to retirements by the year 2000. This finding suggests that numerical retirements and hiring may be consistent at the doctoral level. The results also indicate that greater emphasis on preparing a future generation of aviation faculty members with earned doctorates is becoming increasingly important. In addition, the data indicate that preparing aviation faculty members for careers in community college settings is also an area of increasing importance. The results of the study indicate that 62.5 percent $(\underline{N}=35)$ of all the UAA respondents require, at a minimum, the master's degree for aviation faculty new hires. Significantly less $(\underline{N}=7,12.5 \%)$ require the doctorate.

In the area of collegiate aviation's effectiveness in promoting and preparing a future generation of faculty members, 22 respondents $(39.3 \%)$ reported Average. Below Average and Poor responses equated to nearly one-half of the respondents $(\underline{N}=25,44.6 \%)$. In a related area, almost all of the UAA respondents $(\underline{N}=55,98.2 \%)$ believe the public at large does not have an adequate understanding of collegiate aviation. Clearly, promoting aviation faculty careers and public awareness are two areas that collegiate aviation needs to improve upon.

The most commonly reported salary ranges are as follows: $\$ 40,000$ - $\$ 59,000$ $(\underline{\mathrm{N}}=36,64.3 \%)$ and $\$ 20,000-\$ 39,000(\underline{\mathrm{N}}=32$, $57.1 \%)$. The national average reported by the US Department of Education (cited in The Chronicle of Higher Education: Almanac Issue, 1997) for all professors (except those institutions without academic ranks) is $\$ 52,556$. Nearly one-half of the UAA members $(\underline{N}=26,46.4 \%)$ believe their program salaries are average with respect to cost of living while an additional 13 
$(\underline{N}=23.2 \%)$ report their program salary structure is good.

\section{Recommendations}

Historically, other studies (Matson, 1977; Taylor, 1990; Truitt \& Kaps, 1995; Johnson, 1997) have indicated that negative public perception of collegiate aviation has been problematic. Despite great strides in collegiate aviation in a relatively short period of time, inadequate public awareness still presents a problem as indicated by the data collected for this study. The identity issue still plagues collegiate aviation. How aviation educators are collectively identified in the academic field still remains obscure at best. Johnson (1997) found 14 different terms or phrases were used by aviation educators to identify collegiate aviation. The study also found a disturbing observation noted by several traditional scholars with no previous aviation experience: If aviation educators and scholars cannot articulate who they are as a collective body, then how do they expect us and the general public to identify who they are as well?

One solution is to redefine or invent a collective term or phrase to describe what we do and how we identify ourselves. By 1997, Johnson (1997) invented the word aeronology as "the study of the nonengineering aspects of aviation, aeronautics, and aerospace sciences and technologies" ( $\mathrm{p}$. 28). In the field of engineering, Narayanan (1999) has made reference to aeronology "as a subject bridging various disciplines in aerospace sciences" (p. 11) in a research proposal to the National Science Foundation (NSF). Regardless of what word or phrase is used, it is recommended that aviation as an academic field of study should resolve the identity issue. This should alleviate some internal and external perceptual problems.

Other recommendations include elevating the awareness of aviation related higher education opportunities to students and industry representatives. This can be accomplished at the institutional level or through involvement in national organizations such as UAA conferences. As the importance of aviation related research further escalates, the need to prepare a future generation of faculty members with earned doctorates becomes more imperative as well. By doing so, the academic vitality of aviation will be preserved by the preparation of a new generation of faculty members capable of addressing the demands of the twenty-first century and beyond. 


\section{REFERENCES}

Collegiate Aviation Guide. (1994). Auburn, AL: University Aviation Association.

Fuller, M. \& Truitt, L. (1997). Aviation education: Perceptions of airport consultants. Journal of Air Transportation World Wide, 2(1), 64-80.

Johnson, J. A. (1993). The feasibility of developing a professionally accredited nonengineering aeronautical/aerospace science doctoral degree program in US universities (Master's thesis, Embry-Riddle Aeronautical University, 1993). Master's Abstracts International, 32/01, 24.

Johnson, J. A. (1997). An analysis of curriculum design in developing a doctor of philosophy program in aeronology (Doctoral dissertation, Bowling Green State University, 1997). Dissertation Abstracts International, 58-08A, 3037.

Matson, R. (1977). The book of aerospace education. Washington, DC: American Society for Aerospace Education.

Minitab for Windows 12.2 [Computer Software]. (1998). State College, PA: Minitab, Inc.

Narayanan, R. (1999). Establishment of the University of Nebraska airborne remote sensing facility (NSF research proposal). Lincoln, NE: Author.

Taylor, K. (1990). The marketability of an aviation-related doctoral degree. Unpublished manuscript, Embry-Riddle Aeronautical University. Daytona Beach, FL.

The Chronicle of Higher Education: Almanac Issue. (1997, August). Washington, DC: The Chronicle of Higher Education.

Truitt, L. \& Kaps, R. (1995). Publishing aviation research: An Interdisciplinary review of scholarly journals. Journal of Studies in Technical Careers, XV(4), 229-243. 


\section{REFERENCES}

Astin, A. W. (1985). Achieving educational excellence. San Francisco: Jossey-Bass.

Astin, A. W. (1991). Assessment for excellence: The philosophy and practice of assessment and evaluation in higher education. New York: MacMillan.

Bogue, E. G., \& Saunders, R. L. (1992). The evidence for quality. San Francisco: Jossey-Bass.

Cameron, K. S. (1987). Improving academic quality and effectiveness, in M. W. Peterson and L. A. Mets (Eds.) Key resources on higher education governance, management, and leadership, pp. 322-346. San Francisco: Jossey-Bass.

Clark, M. J. (1983). Graduate program self-assessment service: Handbook for users. Princeton, NJ: Educational Testing Service.

Conrad, C. F., \& Blackburn, R. T. (1985b). Program quality in higher education: A review and critique of literature and research. In Higher education: Handbook of theory and research, Vol. 1, pp. 283-308. New York: Agathon Press.

Conrad, C. F., \& Pratt, A. M. (1985). Designing for quality. Journal of Higher Education, 56 (6) 601-621.

ETS. (1996). Program Self-Assessment Service. Princeton, NJ: Educational Testing Service.

Fairweather, J. S., \& Brown, D. F. (1991). Dimensions of academic program quality. The Review of Higher Education, 14 (2) 155-176.

Kolb, D. A. (1984). Experiential learning: Experience as the source of learning development. Englewood Cliffs, NJ: Prentice Hall.

Kuh, G. D. (1981). Indices of quality in the undergraduate experience. AAHE-ERIC Higher Education Research Report No. 4. Washington, D.C.: American Association for Higher Education.

Kuh, G. D., Schuh, J. H., Whitt, E. J. \& Associates. (1991). Involving colleges. San Francisco: Jossey-Bass.

Lindseth, P. D. (1998). Developing a model of four-year aviation program quality: A grounded theory approach. Collegiate Aviation Review, Sept. 1998. 11-23.

Lindseth, P. D. (1996). Identifying indicators of program quality in U. S. baccalaureate aviation programs. Dissertation. Ann Arbor, MI. The University of Michigan.

Pace, C. (1990). The undergraduates: A report of their activities and progress in college in the 1980s. Los Angeles: University of California, Center for the Study of Evaluation.

Pace, C. (1984). Measuring the quality of college student experiences. Los Angeles: University of California, Higher Education Research Institute.

Pace, C. (1979). Measuring outcomes of college. San Francisco: Jossey-Bass.

Tan, D. L. (1992). A multivariate approach to the assessment of quality. Research in Higher Education, 33 (2) 205-226. 